\title{
Single-Port Access Laparoscopic Surgery in Gynecology: Technical Tips
}

\author{
Jiheum Paek ${ }^{1}$ and Sang Wun Kim ${ }^{2}$ \\ ${ }^{1}$ Department of Obstetrics and Gynecology, Ajou University School of Medicine, Suwon, \\ 2Division of Gynecologic Oncology, Department of Obstetrics and Gynecology, \\ Yonsei University College of Medicine, Seoul, \\ Korea
}

\section{Introduction}

Numerous studies have reported various laparoscopic techniques since the idea of "minimal invasive access surgery" was introduced in the early 1990s (1). One of them is the transumbilical endoscopic surgery (TUES). TUES is a single-port access (SPA) surgery approach to the umbilicus, an embryologic natural orifice (2). Other names of this technique include SPA surgery, scarless surgery, single-port laparoscopy (3), one-port umbilical surgery, natural orifice transumbilical surgery (4), laparoendoscopic single-site surgery (LESS) (5), and embryonic natural orifice transumbilical endoscopic surgery (6). Recently, with improvements in surgical expertise with optimal instrumentation, the interests of minimally invasive surgery have increased. As a result, many surgeons have tried to reduce the number and size of ports in laparoscopic surgery for reducing morbidity and better cosmetic outcome.

It has been reported that SPA surgery has less postoperative pain compared to conventional laparoscopy in the gynecologic field (7). In addition, SPA surgery is expected to offer better cosmetic results and to reduce operative complications related to the trocar insertion as it involves less inserted trocars (8). However, SPA surgery has systemic limitations, including crashes between instruments or between instruments and endoscope, a limited number of instruments, an unstable camera platform, and the limited mobility of straight laparoscopic instruments because surgical instruments work through only one port. These technical problems cause lower accuracy of the operation and longer operation time compared to conventional laparoscopy. To overcome the technical difficulties, newly developed instruments, including an angled laparoscope or instrument have been introduced. However, there are limitations for popular use of SPA surgery, including high cost. Therefore, we suggest useful surgical techniques for SPA surgery using conventional laparoscopic instruments.

\section{Port placement}

Several commercial port systems have been introduced for SPA laparoscopy. We introduce a home-made single-port system using wound retractor and surgical gloves (Fig. 1). After making a 1.2 1.5-cm vertical intra-umbilical skin incision (Fig. 2), the Alexis ${ }^{\circledR}$ wound 
retractor (Applied Medical, CA, USA) is inserted into the peritoneal cavity through the umbilicus (Fig. 3). Because it is often difficult to remove the wound retractor after surgery, a 1-0 Black Silk is tied at the inner ring of the wound retractor (Fig. 4). An operator has only to pull on the thread that is positioned out of the skin. A 71/2 surgical glove is fixed to the outer ring of the wound retractor. After making small incisions in the finger tip portions of the glove, two 5-mm trocars and one 11- $\mathrm{mm}$ trocar are inserted. A rigid 30-degree, 5-mm, endoscope $45 \mathrm{~cm}$ long is used (Fig. 5A).

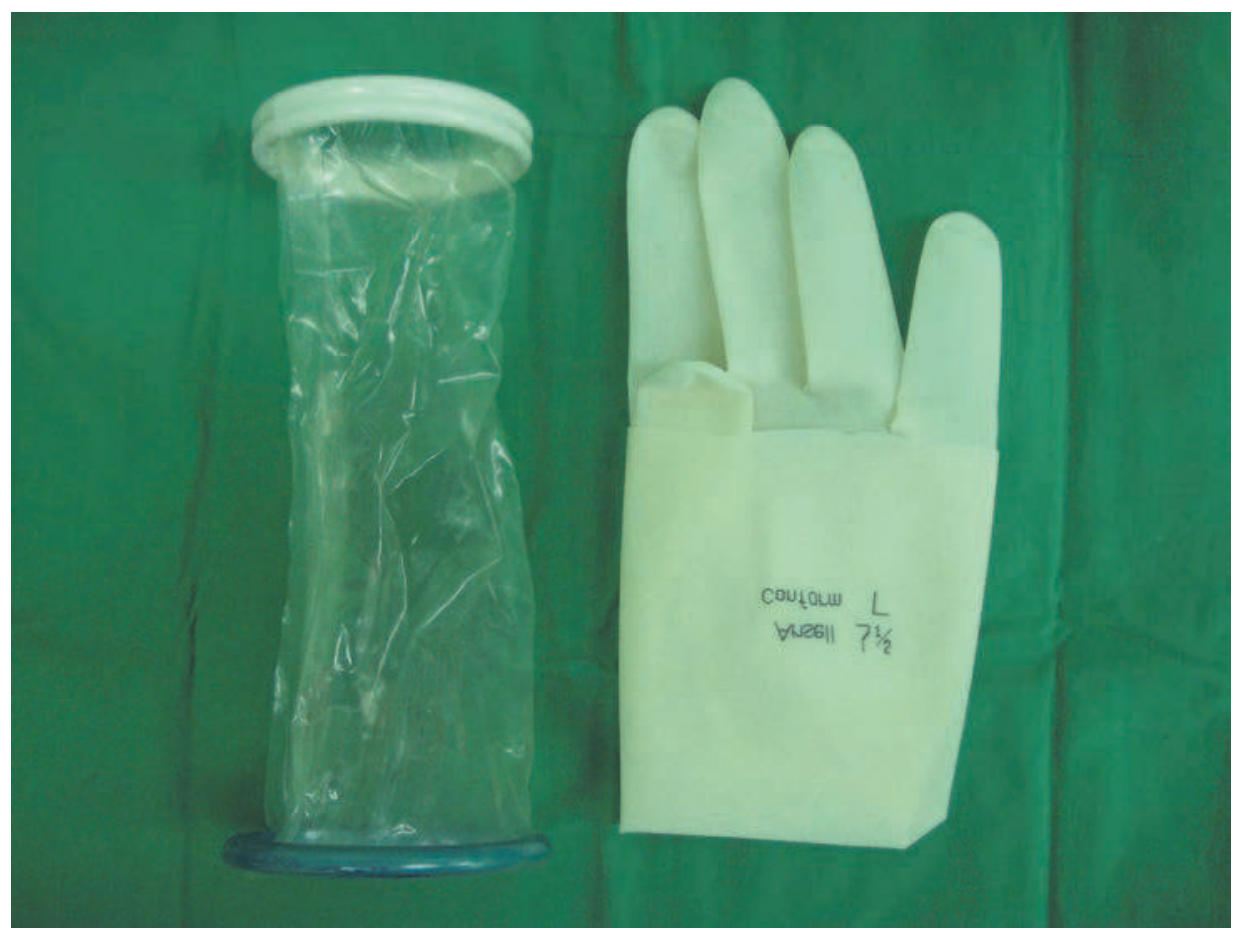

Fig. 1. A homemade single-port system using the Alexis ${ }^{\circledR}$ wound retractor (Applied Medical, CA, USA) and a 71/2 surgical glove. 

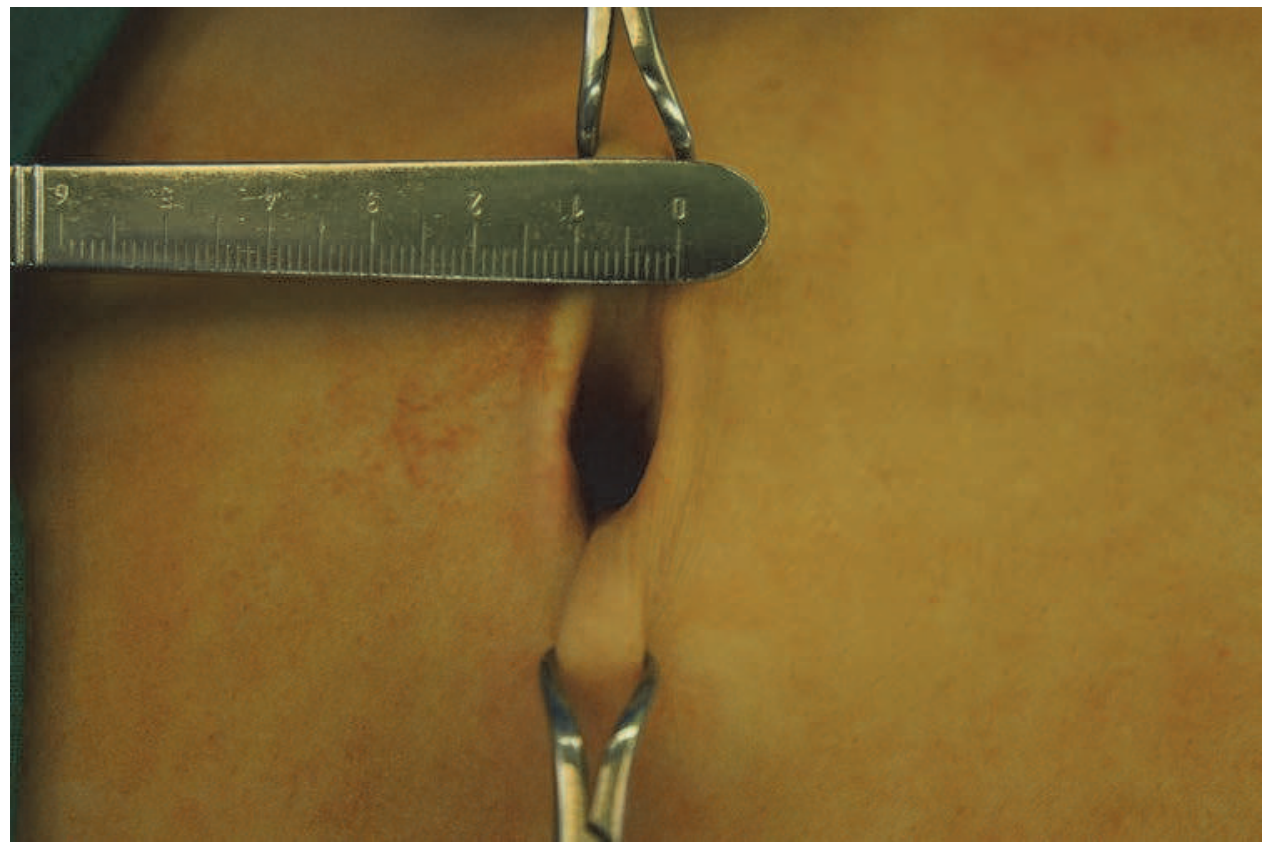

Fig. 2. A 1.5-cm vertical intra-umbilical skin incision.

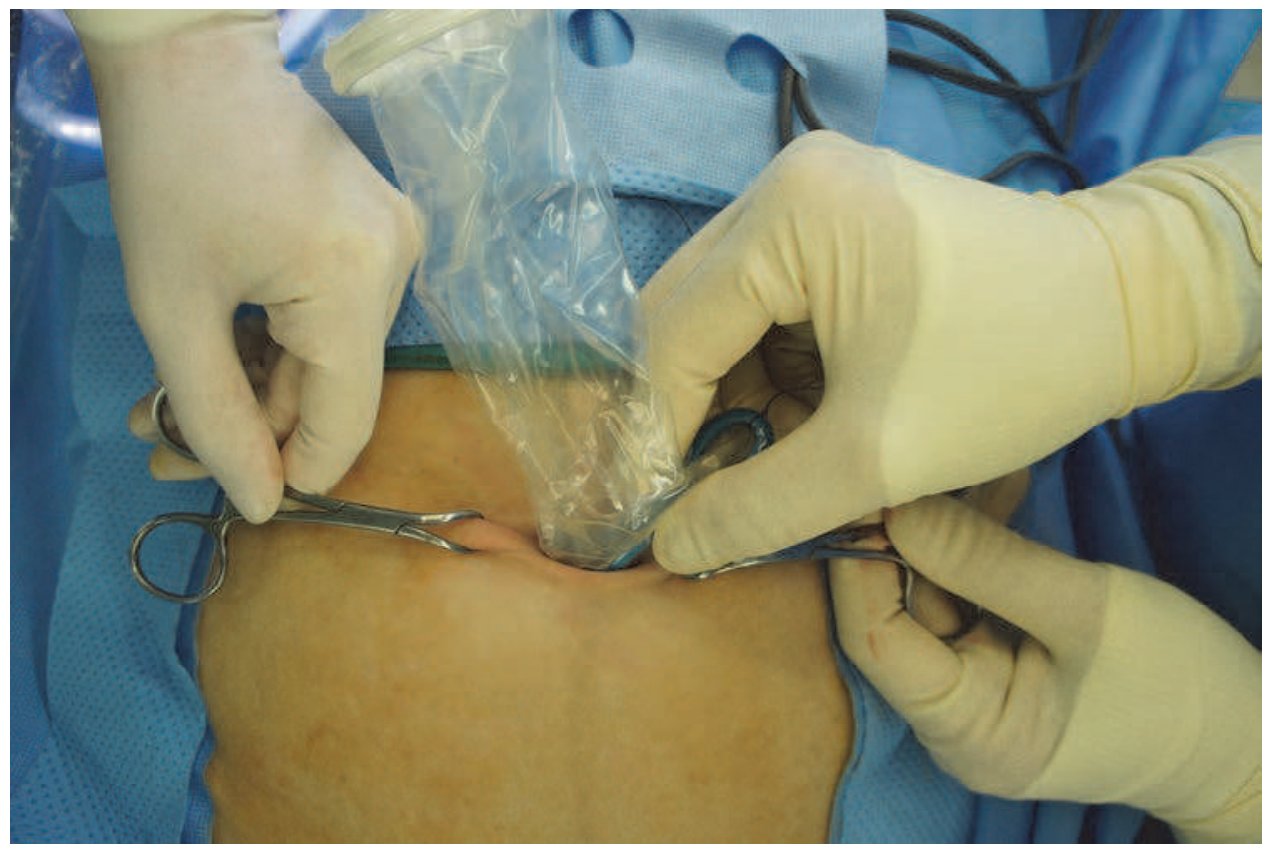

Fig. 3. Insertion of wound retractor into the peritoneal cavity through the umbilicus. 


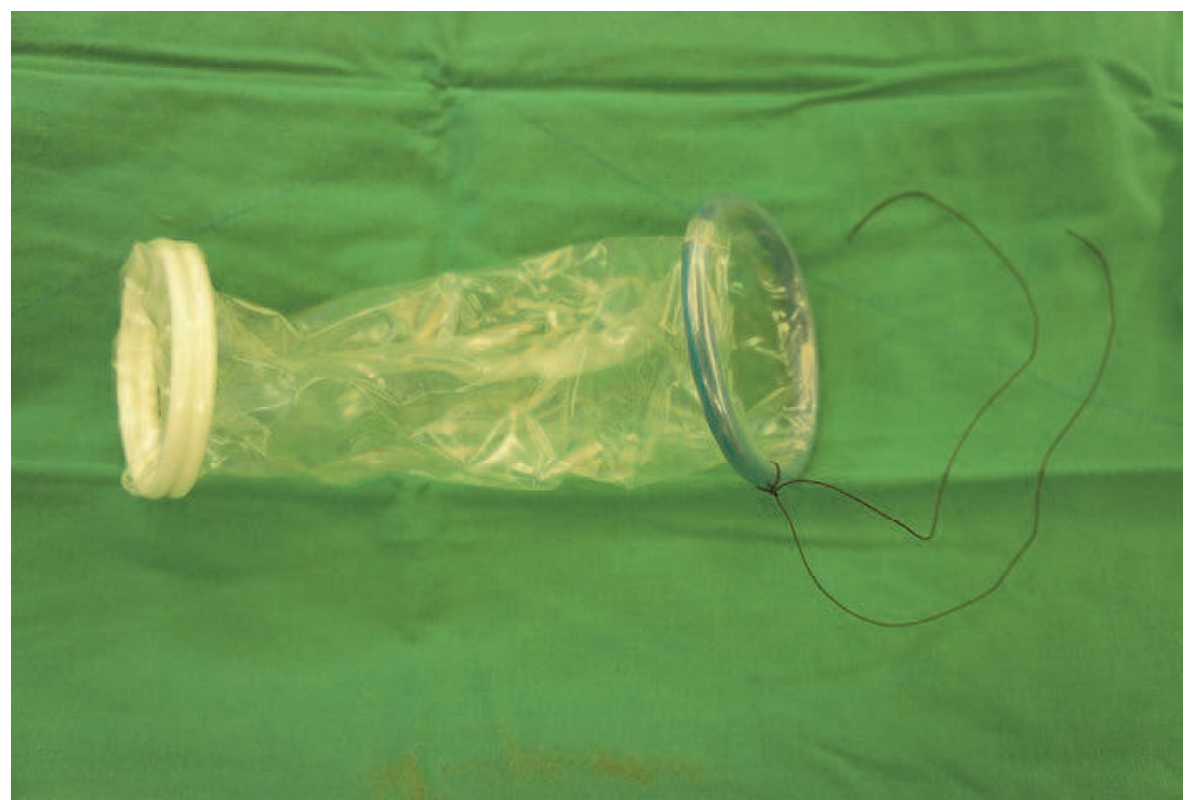

Fig. 4. A 1-0 Black Silk is tied at the inner ring of the wound retractor to remove the wound retractor after surgery.

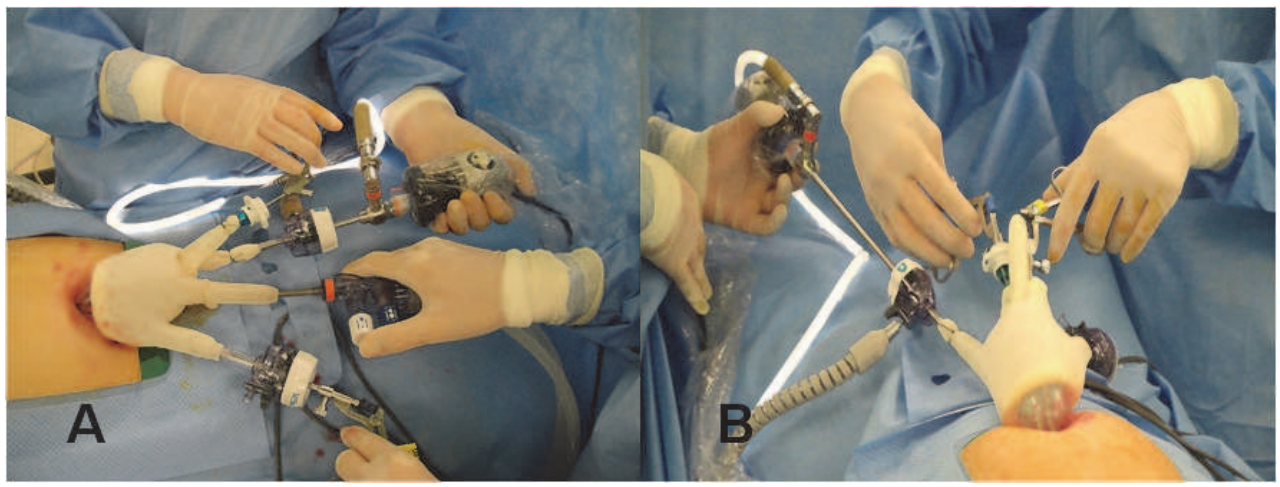

Fig. 5. (A, B) Two 5-mm trocars and one 11-mm trocar are inserted. A rigid 30-degree, 5-mm, endoscope $45 \mathrm{~cm}$ long is used. Using a 5-mm trocar-threaded cannula and seal (Applied medical, CA, USA) and 3-mm hole on the tip of the surgical glove without a trocar.

\section{Surgical applications}

\section{Total laparoscopic hysterectomy (TLH)}

Hysterectomy is the most common surgery in gynecologic field. Recently, it has been reported that hysterectomy using the SPA system was feasible (7, 9-14). For an analysis of SPA hysterectomy other than small case series, Park et al evaluated a total of 105 cases of 
SPA laparoscopy-assisted vaginal hysterectomy (15). In this analysis, 4 of 105 patients needed additional port and one case was converted to a laparotomy. The operating time was $120 \mathrm{~min}$ and the complication rate was $4 \%$. In addition, the authors analyzed the learning curve of 100 consecutive patients underwent SPA-TLH. There was no conversion to conventional laparoscopy or laparotomy. The median time until the removal of a specimen $\left(T_{R}\right)$ was $45 \mathrm{~min}$ and the median time for closure of the vaginal cuff $\left(\mathrm{T}_{\mathrm{C}}\right)$ was $18 \mathrm{~min}$. The median total operating time from skin opening to closure $\left(T_{O}\right)$ was $80 \mathrm{~min}$. $T_{R}, T_{C}, T_{O}$, and decreased significantly over the study period. The $T_{C}$ decreased significantly from the first 20 cases to the next $20(\mathrm{p}=0.028)$ and the $\mathrm{T}_{\mathrm{O}}$ from the second 20 cases to the next $20(\mathrm{p}=$ 0.029). Compared to multiple-port access TLH, SPA-TLH seems to be feasible without increased complication rates and is expected to have an improved cosmesis with the surgical incision hidden in the umbilicus.

\section{Laparoscopic adnexal surgery}

It is important issue for most of woman to have less surgical scar regardless of age. Moreover, age of woman who undergo an adnexal surgery is younger compared to other gynecologic surgery. In addition, the specimen can be easily removed through a laparoscopic bag inserted through an umbilical trocar. When surgical gloves and wound retractor are used for an umbilical port, $1.5 \mathrm{~cm}$ incision in the umbilicus is more useful to remove the specimen compared to conventional laparoscopy or commercial single port system. However, it is not always easy to perform an SPA adnexal surgery in severe endometriosis or huge ovarian tumor. Therefore, the SPA adnexal surgery often needs to have surgical techniques and experiences.

\section{Others}

Escobar et al reported a retrospective, multi-institutional analysis of BRCA carriers and women at high risk for breast/ovarian cancer who underwent LESS risk-reducing salpingooophorectomy with and without hysterectomy. A total of 58 patients were evaluated surgical proficiency was possible after 10-15 cases in this study (16). Additionally, for gynecologic cancer operation, lymph node dissection with single-port has been introduced (17).

\section{Technical tips with conventional instruments}

The authors have performed more than 400 SPA laparoscopy surgeries in the gynecologic field. Based on our abundant experiences, we have introduced surgical tips to overcome technical difficulties in SPA surgery (18). A collision between the camera and surgical instruments is one of problems with which the operator is faced in SPA surgery. With a 0degree endoscope, the endoscope and the surgical instrument are positioned in parallel to each other, which limits the field of vision and makes it difficult to avoid collision between the endoscope and the surgical instruments. The use of a 30-degree endoscope provides the operator a wider vision. In this situation, the endoscope is not in parallel with the surgical instruments and can keep a distance from the instruments without a change of the visual field. By changing the angle of the endoscope via the endoscope-holder, the operator can accurately see the structure that he intends to operate on, and can avoid instrumental collision as well. Moreover, the operator can see the field that is invisible when using a 0-degree endoscope. The collision between the light cable and the operator's hands often occurs because the angle between the light cable and the endoscope is generally $90^{\circ}$. Such a collision can be avoided by 
using a 90-degree light cable adaptor. Generally, the length of a commonly used endoscope is $30 \mathrm{~cm}$. However, the $45-\mathrm{cm}$ endoscope that enables the head of the camera and the light cable to be positioned $15 \mathrm{~cm}$ behind of the operator's hands can effectively prevent the collision between the camera and the operator's hands (Fig. 5B).

A collision between trocars is caused by the head portion of the trocar which is greater in size compared with a diameter of the trocar. Such a collision can be avoided by using a trocar with a smaller-sized head portion, such as a 5-mm trocar-threaded cannula and seal (Applied medical, CA, USA). In addition, to avoid the collision between the trocars, we make an approximately 3-mm hole on the tip of the surgical glove that forms a part of the SPA system without using a trocar. Then, a singular instrument is inserted through the holes of the glove (Fig. 5B).

In some circumstances, it may require one additional instrument for grasping tissue or traction. Particularly, there are many cases that one grasper is not sufficient for surgical procedures, such as dissection of an ovarian tumor, coagulation after dissection, and dissection of pelvic adhesion. The surgical glove may allow simultaneously insertion of up to 5 surgical instruments, which means a maximum of 4 surgical instruments other than the endoscope. The 2-mm grasper (Christian Diener Gmbh. \& CO. K.G., Germany) can be used without increasing the length of the umbilical incision, and this instrument is flexible so that adding it does not cause a crash with other surgical instruments (Fig. 6).

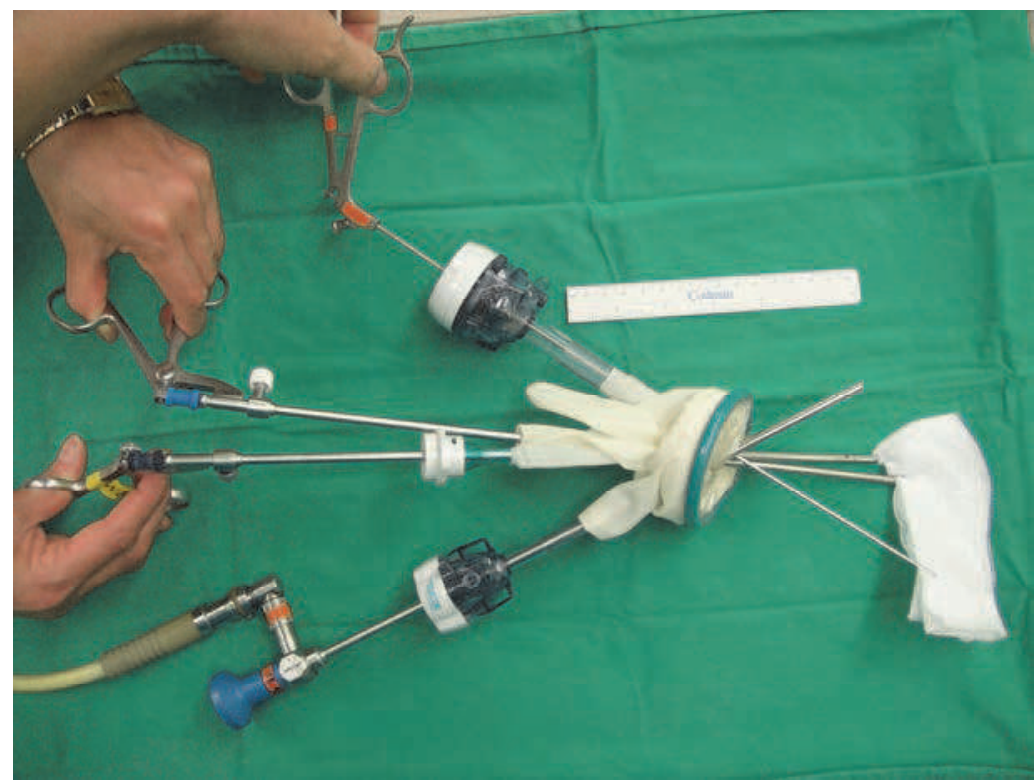

Fig. 6. An additional 2-mm instrument can be used to perform traction of tissue.

Suturing and tying can be the most difficult procedure in surgical techniques for SPA surgery. In gynecologic surgery, suturing and tying are mostly performed to close the vaginal cuff after a hysterectomy or to repair the uterine wall after a myomectomy or parenchyma of ovary after cystectomy. Because these operations are parts of the most common surgeries in gynecology and the incidence of using the SPA system continues to 
rise, it is necessary to find the most effective and accurate method of suturing and tying which is specifically suitable for these surgeries. Among conventional instruments, a needle holder which has a curved end seems to be the most adequate instrument for SPA laparoscopic surgery. The curved end of the needle holder allows the operator to have an optimal angle between the needle and tissue of the vaginal cuff. Besides, the handle is so simple that the operator can easily control it without much collision with other instruments. The suture could be knotted extracorporeally or intracorporeally. For extracorporeal tying, 90-cm long sutures and the Clarke-Reich knot pusher (Cook Medical, IN, USA) are needed. Because there are technical difficulties to perform an intracorporeal tying, reducing the number of intracorporeal tying could be helpful. The first intracorporeal tying could be omitted by making a slipknot on the tip of a suture before inserting the suture in the abdominal cavity (Fig. 7).

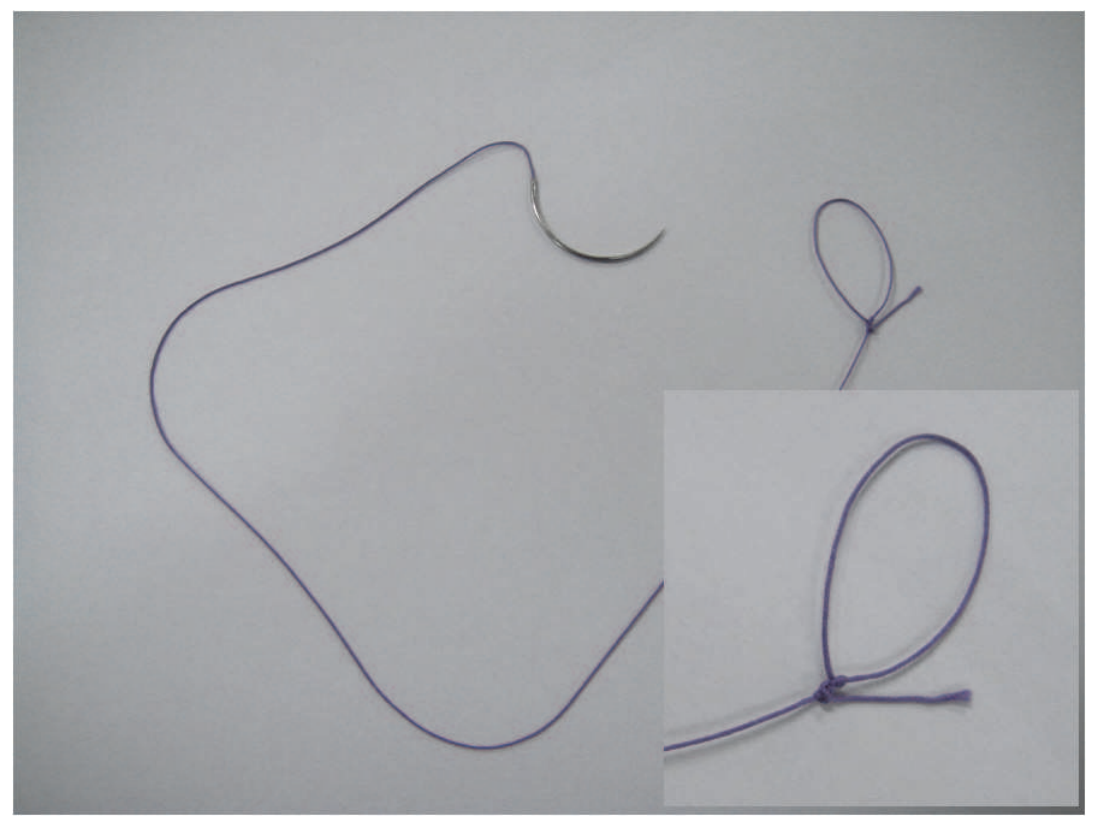

Fig. 7. The first intracorporeal tying can be omitted by making a slipknot on the tip of a suture

\section{Conclusion}

As the technical difficulties are overcome, SPA laparoscopic surgery will be a more and more widespread procedure in gynecology with only minimal skin incision.

\section{References}

[1] Podolsky ER, Rottman SJ, Poblete H, King SA, Curcillo PG. Single port access (SPA) cholecystectomy: a completely transumbilical approach. Journal of laparoendoscopic \& advanced surgical techniques. 2009;19(2):219-22. 
[2] Remzi FH, Kirat HT, Kaouk JH, Geisler DP. Single-port laparoscopy in colorectal surgery. Colorectal disease. 2008;10(8):823-6.

[3] Cuesta MA, Berends F, Veenhof AA. The "invisible cholecystectomy": A transumbilical laparoscopic operation without a scar. Surgical Endoscopy. 2008;22(5):1211-3.

[4] Nguyen NT, Reavis KM, Hinojosa MW, Smith BR, Wilson SE. Laparoscopic transumbilical cholecystectomy without visible abdominal scars. Journal of gastrointestinal surgery. 2009;13(6):1125-8.

[5] Fader AN, Escobar PF. Laparoendoscopic single-site surgery (LESS) in gynecologic oncology: technique and initial report. Gynecologic Oncology. 2009;114(2):157-61.

[6] Canes D, Desai M, Aron M, Haber G, Goel RK, Stein RJ, et al. Transumbilical single-port surgery: evolution and current status. European urology. 2008;54(5):1020-9.

[7] Yim GW, Jung YW, Paek J, Lee SH, Kwon HY, Nam EJ, et al. Transumbilical single-port access versus conventional total laparoscopic hysterectomy: surgical outcomes. American journal of obstetrics and gynecology. 2010;203(1):26.e1-.e6.

[8] Desai M, Rao P, Aron M, Pascal-Haber G, Desai MR, Mishra S, et al. Scarless single port transumbilical nephrectomy and pyeloplasty: first clinical report. BJU international. 2008;101(1):83-8.

[9] Jung YW, Kim YT, Lee DW, Hwang YI, Nam EJ, Kim JH, et al. The feasibility of scarless single-port transumbilical total laparoscopic hysterectomy: initial clinical experience. Surg Endosc2009.

[10] Lee YY, Kim TJ, Kim CJ, Kang H, Choi CH, Lee JW, et al. Single-port access laparoscopic-assisted vaginal hysterectomy: a novel method with a wound retractor and a glove. J Minim Invasive Gynecol. 2009 Jul-Aug;16(4):450-3.

[11] Kim TJ, Lee YY, Cha HH, Kim CJ, Choi CH, Lee JW, et al. Single-port-access laparoscopic-assisted vaginal hysterectomy versus conventional laparoscopicassisted vaginal hysterectomy: a comparison of perioperative outcomes. Surg Endosc. 2010 Sep;24(9):2248-52.

[12] Song T, Kim TJ, Kim MK, Park H, Kim JS, Lee YY, et al. Single port access laparoscopicassisted vaginal hysterectomy for large uterus weighing exceeding 500 grams: technique and initial report. J Minim Invasive Gynecol. 2010 Jul-Aug;17(4):456-60.

[13] Yoon G, Kim TJ, Lee YY, Kim CJ, Choi CH, Lee JW, et al. Single-port access subtotal hysterectomy with transcervical morcellation: a pilot study. J Minim Invasive Gynecol. 2010 Jan-Feb;17(1):78-81.

[14] Jung YW, Lee M, Yim GW, Lee SH, Paek JH, Kwon HY, et al. A randomized prospective study of single-port and four-port approaches for hysterectomy in terms of postoperative pain. Surg Endosc. 2011 Feb 7.

[15] Park HS, Kim TJ, Song T, Kim MK, Lee YY, Choi CH, et al. Single-port access (SPA) laparoscopic surgery in gynecology: a surgeon's experience with an initial 200 cases. Eur J Obstet Gynecol Reprod Biol. 2011 Jan;154(1):81-4.

[16] Escobar PF, Starks DC, Fader AN, Barber M, Rojas-Espalliat L. Single-port riskreducing salpingo-oophorectomy with and without hysterectomy: surgical outcomes and learning curve analysis. Gynecol Oncol. 2010 Oct;119(1):43-7.

[17] Hahn HS, Kim YW. Single-port laparoscopic pelvic lymph node dissection with modified radical vaginal hysterectomy in cervical cancer. Int J Gynecol Cancer. 2010 Nov;20(8):1429-32.

[18] Paek J, Nam EJ, Kim YT, Kim SW. Overcoming technical difficulties with single-port access laparoscopic surgery in gynecology: using conventional laparoscopic instruments. J Laparoendosc Adv Surg Tech A. 2011 Mar;21(2):137-41. 


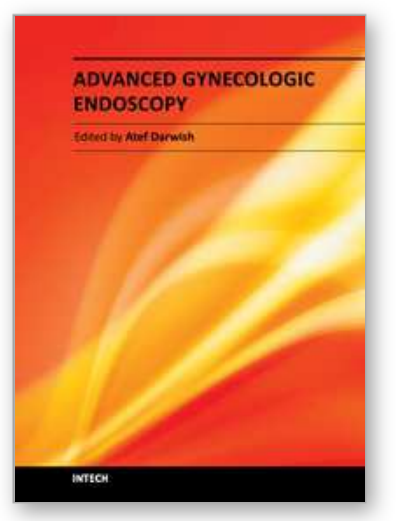

\author{
Advanced Gynecologic Endoscopy \\ Edited by Dr. Atef Darwish
}

ISBN 978-953-307-348-4

Hard cover, 332 pages

Publisher InTech

Published online 23, August, 2011

Published in print edition August, 2011

The main purpose of this book is to address some important issues related to gynecologic laparoscopy. Since the early breakthroughs by its pioneers, laparoscopic gynecologic surgery has gained popularity due to developments in illumination and instrumentation that led to the emergence of laparoscopy in the late 1980's as a credible diagnostic as well as therapeutic intervention. This book is unique in that it will review common, useful information about certain laparoscopic procedures, including technique and instruments, and then discuss common difficulties faced during each operation. We also discuss the uncommon and occasionally even anecdotal cases and the safest ways to deal with them. We are honored to have had a group of world experts in laparoscopic gynecologic surgery valuably contribute to our book.

\title{
How to reference
}

In order to correctly reference this scholarly work, feel free to copy and paste the following:

Jiheum Paek and Sang Wun Kim (2011). Single-Port Access Laparoscopic Surgery in Gynecology: Technical Tips, Advanced Gynecologic Endoscopy, Dr. Atef Darwish (Ed.), ISBN: 978-953-307-348-4, InTech, Available from: http://www.intechopen.com/books/advanced-gynecologic-endoscopy/single-port-access-laparoscopicsurgery-in-gynecology-technical-tips

\section{INTECH}

open science | open minds

\section{InTech Europe}

University Campus STeP Ri

Slavka Krautzeka 83/A

51000 Rijeka, Croatia

Phone: +385 (51) 770447

Fax: +385 (51) 686166

www.intechopen.com

\author{
InTech China \\ Unit 405, Office Block, Hotel Equatorial Shanghai \\ No.65, Yan An Road (West), Shanghai, 200040, China \\ 中国上海市延安西路65号上海国际贵都大饭店办公楼 405 单元 \\ Phone: +86-21-62489820 \\ Fax: +86-21-62489821
}


(C) 2011 The Author(s). Licensee IntechOpen. This chapter is distributed under the terms of the Creative Commons Attribution-NonCommercialShareAlike-3.0 License, which permits use, distribution and reproduction for non-commercial purposes, provided the original is properly cited and derivative works building on this content are distributed under the same license. 